\title{
KONSUMSI PANGAN, PENYAKIT INFEKSI, DAN STATUS GIZI ANAK BALITA PASCA PERAWATAN GIZI BURUK
}

\author{
(Food Consumption, Infectious Diseases, and Nutritional Status of Children Under-five Years \\ Post Treatment of Malnutrition)
}

Karlina Nurcahyo ${ }^{1}$ dan Dodik Briawan ${ }^{1 *}$

1 Departemen Gizi Masyarakat, Fakultas Ekologi Manusia, Institut Pertanian Bogor, Bogor 16680.

* Departemen Gizi Masyarakat, Fakultas Ekologi Manusia, Institut Pertanian Bogor, Bogor 16680. Alamat korespondensi: Departemen Gizi Masyarakat, Fakultas Ekologi Manusia, Institut Pertanian Bogor, Bogor 16680. Telp: 0251-8621258; Fax: 0251-8622276, Email: dbriawan@yahoo.com

\begin{abstract}
The research objective was to determine food consumption, infectious diseases, and nutritional status of children under-five years old after the treatment of severe malnutrition at Puskesmas. The cross-sectional study design was conducted in four sub-districs in Bogor. The number of 27 children was selected purposively out of 44 patients at the Puskesmas. The results showed that $88.9 \%$ and $77.8 \%$ of children consumed less than $70 \%$ RDA of energy and protein. In the last three months, the most children suffered from diarrhoea (55.6\%) and ARI (59.3\%). There were $81.5 \%$ of children still in severe malnutrition and only $18.5 \%$ of them shifted to the moderate malnutrition.
\end{abstract}

Key words: severe malnutrition, infectious diseases, post-treatment, children under-five years.

\section{PENDAHULUAN}

Masalah gizi utama yang sampai saat ini masih dihadapi oleh Indonesia adalah kekurangan energi dan protein (KEP). Hasil Riset Kesehatan Dasar (Riskesdas) tahun 2007 menunjukkan bahwa $18.4 \%$ balita menderita KEP dan $5.4 \%$ diantaranya kategori KEP berat (gizi buruk). Berdasarkan laporan dari Dinas Kesehatan seluruh Indonesia terjadi penurunan kasus gizi buruk yaitu pada tahun 2005 terdata 76,178 kasus kemudian turun menjadi 50.106 kasus pada tahun 2006 dan 39,080 kasus pada tahun 2007. Penurunan kasus gizi buruk ini belum dapat dipastikan karena penurunan kasus yang terjadi kemungkinan juga disebabkan adanya kasus yang tidak terlaporkan (Depkes RI, 2008a). Media sering melaporkan adanya masalah gizi buruk di berbagai wilayah di Indonesia.

Salah satu upaya pemerintah untuk mencegah terjadinya gizi buruk, terutama di wilayah rawan pangan dan gizi, telah ditetapkan kebijakan respon cepat penanggulangan gizi buruk. Langkah ini sebagai salah satu upaya untuk lebih mengaktifkan kembali surveilans gizi terutama dalam pelaksanaan Sistem Kewaspadaan Dini Kejadian Luar Biasa (SKD-KLB) Gizi Buruk di seluruh Indonesia (Depkes RI, 2008a).
Prevalensi gizi buruk yang terjadi pada anak balita di Kabupaten Bogor berdasarkan $\mathrm{BB} / \mathrm{U}$ sebesar $3.4 \%$; sedangkan berdasarkan $\mathrm{TB} / \mathrm{U}$ sebesar $14.8 \%$; dan berdasarkan $\mathrm{BB} / \mathrm{TB}$ sebesar 3.9\% (Depkes RI, 2008b). Hal ini menunjukkan bahwa kasus gizi buruk pada anak balita di Kabupaten Bogor masih menjadi masalah yang perlu mendapat perhatian dan penanganan yang serius.

Departemen Kesehatan (2008) telah mengupayakan penjaringan kasus gizi buruk secara dini melalui kegiatan operasi timbang untuk seluruh balita yang pelaksanaannya turut melibatkan sektor lain. Balita yang ditemukan di lapang akan segera divalidasi dan dirujuk ke Rumah Sakit atau Puskesmas bila terdeteksi gizi buruk berdasarkan indeks BB/TB.

Saat ini penanganan gizi buruk tidak hanya terpusat pada rumah sakit tetapi diarahkan supaya Puskesmas mempunyai kemampuan dalam penanganan gizi buruk. Perawatan gizi buruk dapat dilakukan secara rawat inap maupun rawat jalan di Puskesmas melalui klinik gizi. Beberapa kejadian di Kabupaten Bogor setelah anak balita menjalani program perawatan, yang kemudian kembali ke rumah hasilnya menjadi beragam. Pada beberapa kasus diduga pasca pemulihan gizi buruk, kondisi anak balita dapat kembali mengalami gizi buruk setelah kembali ke rumah. Penelitian Arnelia et al. (1992) menunjukkan sebanyak 20\% anak balita 
yang awalnya menderita gizi buruk, pasca pemulihan di klinik gizi (Pusat Penelitian Gizi dan Manakan, Kemenkes) masih dalam kondisi gizi buruk.

Hal ini menunjukkan bahwa ada suatu hal yang menyebabkan berulangnya kondisi gizi buruk tersebut. Sampai saat ini, penelitian mengenai kondisi anak balita pasca perawatan gizi buruk masih sangat terbatas. Oleh karena itu, penelitian ini dilakukan untuk mempelajari dan mengkajinya.

\section{METODE}

\section{Desain, Tempat, dan Waktu}

Penelitian dilaksanakan menggunakan desain cross-sectional study. Lokasi penelitian di empat kecamatan, yaitu Kecamatan Dramaga, Ciampea, Cibungbulang, dan Leuwiliang. Penentuan keempat wilayah kecamatan tersebut sebagai lokasi penelitian dilakukan secara purposive. Penelitian dilakukan pada bulan Juli 2010.

\section{Jumlah dan Cara Penarikan Sampel}

Penarikan contoh dilakukan secara purposive dengan kriteria inklusi adalah anak balita berusia 12-59 bulan, selesai rawat jalan karena gizi buruk, tinggal bersama ibu kandung, dan bersedia menjadi contoh. Laporan dari Dinas Kesehatan Kabupaten Bogor, yang kemudian diverifikasi di masing-masing Puskesmas, diperoleh sebanyak 44 anak balita pernah mendapatkan perawatan gizi buruk. Anak balita yang memenuhi kriteria inklusi adalah 27 anak, dan selebihnya sebanyak 17 anak yang termasuk kriteria eksklusi karena dirawat di Puskesmas diluar periode November 2009 - Mei 2010, disertai tanda klinis, mengalami hipoglikemia, hipotermia, dan dehidrasi, sudah meninggal.

Pengumpulan data primer dilakukan melalui wawancara menggunakan kuesioner kepada ibu balita gizi buruk. Data tersebut meliputi karakteristik rumahtangga (usia, pendidikan, dan pekerjaan orangtua; pendapatan rumahtangga; dan besar rumahtangga); karakteristik anak balita (jenis kelamin, usia, urutan anak dalam keluarga, riwayat kelahiran, penyakit penyerta saat identifikasi oleh petugas Puskesmas, dan riwayat pemberian ASI); konsumsi pangan (makanan dari rumah dan PMT Puskesmas) dengan menggunakan recall 1×24 jam; frekuensi makan pasca perawatan; pola asuh makan; penyakit infeksi (diare dan ISPA) selama tiga bulan lalu; dan status gizi anak balita. Berat badan diperoleh dari penimbangan dengan timbangan bayi (baby scale) dengan ketelitian $0.1 \mathrm{~kg}$. Panjang badan diukur dengan menggunakan alat ukur panjang badan dari kayu (length board) dengan ketelitian $0.1 \mathrm{~cm}$.

\section{Pengolahan dan Analisis Data}

Status gizi anak balita dinilai berdasarkan BB/U, TB/U, dan BB/TB yang diolah menggunakan software WHO Anthro 2007. Hasil data status gizi anak balita berdasarkan ketiga indeks antropometri (BB/U, TB/U, dan BB/TB) kemudian diinterpretasikan berdasarkan gabungan dari ketiga indeks tersebut (WHO, 2005). Interpretasi status gizi ini adalah berdasarkan kategori nilai Z-score (SD), yaitu Tinggi (T) jika SD $>2$, Normal (N) jika $-2<\mathrm{SD}<2$, dan Rendah (R) jika SD<-2 (Tabel 1).

Uji korelasi Pearson dilakukan untuk mengetahui hubungan antara tingkat kecukuan energi (TKE) dan protein (TKP), frekuensi diare dan ISPA dengan status gizi anak balita.

Tabel 1. Interpretasi Status Gizi berdasarkan Gabungan Indeks Antropometri

\begin{tabular}{cccl}
\hline BB/TB & BB/U & TB/U & \multicolumn{1}{c}{ Status Gizi } \\
\hline N & R & R & Baik, pernah kurang gizi \\
N & N & N & Baik \\
N & T & T & Jangkung, baik \\
R & $\mathrm{R}$ & $\mathrm{T}$ & Buruk \\
$\mathrm{R}$ & $\mathrm{R}$ & $\mathrm{N}$ & Buruk, kurang \\
$\mathrm{R}$ & $\mathrm{N}$ & $\mathrm{T}$ & Kurang \\
$\mathrm{T}$ & $\mathrm{T}$ & $\mathrm{R}$ & Lebih, kemungkinan kegemukan \\
$\mathrm{T}$ & $\mathrm{N}$ & $\mathrm{R}$ & Lebih, pernah kurang gizi \\
$\mathrm{T}$ & $\mathrm{T}$ & $\mathrm{N}$ & Lebih tetapi tidak kegemukan \\
$\mathrm{R}$ & $\mathrm{R}$ & $\mathrm{R}$ & Buruk, sejak dulu sampai sekarang \\
$\mathrm{N}$ & $\mathrm{R}$ & $\mathrm{N}$ & Baik, perbatasan dengan kurang \\
$\mathrm{N}$ & $\mathrm{N}$ & $\mathrm{R}$ & Baik, catch-up growth belum sempurna \\
\hline
\end{tabular}

Sumber: Arnelia et al. (1992) 


\section{HASIL DAN PEMBAHASAN}

Penatalaksanan klinik gizi di Puskesmas merupakan suatu tim yang terdiri atas dokter, Tenaga Pelaksana Gizi (TPG), perawat, bidan, dan petugas promosi kesehatan Puskesmas. Berdasarkan informasi dari TPG, penatalaksanaan klinik gizi dilakukan dengan beberapa tahapan. Tatalaksana pelayanan gizi buruk secara rawat jalan di klinik gizi di Puskesmas terdiri atas enam tahap, yaitu 1) pengkajian status gizi yang meliputi antropometri, pemeriksaan fisik, dan laboratorium (pemeriksaan laboratorium hanya untuk kasus tertentu); 2) riwayat gizi yaitu anamnesis riwayat gizi yang dilakukan untuk memperoleh gambaran kebiasaan makan atau pola makan; 3) penentuan kebutuhan gizi yang diberikan berdasarkan status gizi dan pemeriksaan klinis bila perlu dilakukan dengan pemeriksaan laboratorium; 4) penentuan jenis diet, disesuaikan dengan keadaan anak balita gizi buruk. Jenis diet yang diberikan meliputi F75 dan F100, serta pemberian makanan sesuai dengan menu seimbang; 5) konseling gizi, dilakukan dengan tujuan untuk memberikan pengetahuan pada ibu balita dan dapat mengubah serta memperbaiki perilaku makan anak balita; 6) evaluasi dan tindak lanjut, dilakukan pada setiap kegiatan dan bila diperlukan maka dilakukan kunjungan ke rumah.

Penanganan gizi buruk dilakukan melalui 18 kali kunjungan, yaitu untuk kunjungan pertama F75 selama 3 hari dan F100 selama 4 hari tanpa diberikan makanan apapun; kunjungan minggu kedua sampai dengan minggu keenam diberikan makanan F100 tetapi disesuaikan dengan keadaan anak; dan kunjungan minggu ketujuh sampai dengan minggu kedelapan belas diberikan makanan berupa susu formula dan makanan sesuai dengan usia anak.

\section{Karakteristik Keluarga}

Rata-rata usia ayah $35.9 \pm 8.6$ tahun dengan mayoritas pada kategori dewasa madya (55.6\%). Usia ibu sebanyak $59.3 \%$ dalam kategori dewasa muda dengan rata-rata $30.4 \pm 7.6$ tahun. Pendidikan orangtua sebagian besar adalah tamatan Sekolah Dasar (SD), yaitu 44.4\% (ayah) dan 63.0\% (ibu). Pekerjaan ayah sebagian besar adalah buruh (59.2\%) dan sopir angkot (18,5\%), sedangkan $85.2 \%$ ibu sebagai ibu rumahtangga. Rata-rata pendapatan keluarga Rp 987.296 $\pm 476.065 /$ bulan (Rp $185.750 \pm$ 108.464/kapita/bulan). Sebanyak 63.\% rumahtangga mempunyai anggota rumahtangga dengan jumlah 5-7 orang.

\section{Karakteristik Anak Balita}

Karakteristik anak balita meliputi jenis kelamin, usia, urutan anak dalam keluarga, riwayat kelahiran, dan penyakit penyerta saat awal ditangani Puskesmas, dan riwayat pemberian ASI. Sebesar 51.9\% anak balita berjenis kelamin perempuan, dan usia pada kelompok 12-23 bulan (59.3\%), 24-35 bulan (33.3\%), 3647 bulan (3.7\%), dan 48-60 bulan (3.7\%).

Sebanyak $40.7 \%$ anak balita merupakan anak pertama, $18.5 \%$, anak kedua dan ketiga, $3.7 \%$ anak keempat dan $18.5 \%$ anak kelima. Karakteristik anak gizi buruk di Puslitbang Gizi Bogor menunjukkan kebanyakan pasien adalah anak pertama atau kedua (Arnelia, 2009). Kejadian gizi buruk pada anak pertama dapat dimungkinkan karena orangtua anak balita yang masih kurang mengetahui cara perawatan dan pengasuhan anak yang baik. Hal ini sejalan dengan tingkat pendidikan orangtua anak balita yang masih rendah.

Riwayat persalinan anak menunjukkan sebanyak $59.3 \%$ cukup bulan dan $59.3 \%$ berat badan lahir rendah (BBLR). Riwayat penolong persalinan sebagian besar (40.8\%) dilakukan oleh bidan. Keseluruhan anak balita tersebut mempunyai riwayat tidak mendapatkan ASI eksklusif. Anak balita BBLR mempunyai risiko menjadi gizi kurang/buruk jika pola asuh tidak memadai, pelayanan kesehatan kurang, sering terkena infeksi, dan asupan gizi yang kurang. Hasil penelitian Arnisam (2007) anak usia 6-24 bulan yang BBLR mempunyai risiko 3.34 kali lebih besar untuk mengalami gizi kurang $(B B / U<$ $2 \mathrm{SD}$ ). Selain itu asupan energi dan protein kurang 70\% AKG berturut-turut mempunyai risiko 2.9 kali dan 3.1 kali lebih besar untuk menderita status gizi kurang.

Saat awal pemeriksaan di Puskesmas, anak balita menderita beragam penyakit yaitu diare $(40.7 \%)$, ISPA $(37.0 \%)$, kelainan kongenital (18.5\%), dan Koch Pulmonum (3.7\%). Tingkat keparahan penyakit dan status gizi anak berbeda waktu penanganannya oleh Puskesmas karena keterlambatan proses pelacakan/rujukan oleh kader. Sebanyak $7.4 \%$ mendapat perawatan awal pada bulan November; $3.7 \%$ bulan Desember; 44.4\% bulan Januari; $18.5 \%$ masingmasing pada bulan Februari dan April; dan 7.4\% pada bulan Mei. Sehingga rentang waktu pasca perawatan anak balita gizi buruk waktunya berbeda antara dua sampai delapan bulan. Selain itu, kebanyakan ibu tidak patuh untuk melakukan perawatan lanjutan di Puskesmas. 


\section{Konsumsi Pangan dan Asupan Energi-Protein}

Kebiasaan makan anak balita saat awal pasca perawatan sampai studi ini dilakukan tidak banyak berbeda dalam hal frekuensi konsumsi, porsi maupun jenis makanannya. Masih ditemukan anak yang frekuensi konsumsi pangan pokok (nasi) hanya dua kali sehari sebanyak $37.0 \%$. WHO menganjurkan konsumsi pangan anak sesering mungkin karena keterbatasan volume perut anak. Depkes RI (2009) menganjurkan anak 2-3 tahun diberi makan keluarga seperti 3 kali sehari (porsi $1 / 2$ piring) dan makanan selingan 2 kali.

Jenis pangan sumber protein yang paling sering (> 3 kali per minggu) diberikan kepada anak balita adalah telur (55.6\%), dengan penyajian telur dadar, ceplok, maupun orak-arik. Jenis pangan sumber protein lainnya adalah tempe (22.2\%), ikan (11.1\%) dan daging ayam (11.1\%). Frekuensi konsumsi sayuran anak balita pada umumnya 2-3 kali per minggu (22.2\% balita). Jenis sayuran yang dikonsumsi adalah bayam, wortel, dan kangkung. Anak balita selain sangat jarang mengonsumsi sayur juga jarang mengonsumsi buah. Frekuensi konsumsi buah pada umumnya hanya 1 kali per minggu. Jenis buah yang dikonsumsi adalah jeruk, pepaya, dan pisang. Berdasarkan panduan/rekomendasi seharusnya pangan tersebut dikonsumsi tiga kali sehari, sehingga kebiasaan konsumsi pangan sumber protein, sayur, dan buah pada anak balita gizi buruk tersebut masih sangat rendah.

Bahan pangan sumber karbohidrat yang dikonsumsi anak balita terutama adalah nasi, dan kadang-kadang juga bubur ayam, mie instan, dan biskuit. Nasi dikonsumsi oleh seluruh anak balita dengan jumlah rata-rata $126.2 \pm$ 47.2 g. Pangan sumber karbohidrat lainnya adalah bubur ayam, mie instan, dan biskuit yang konsumsinya berturut-turut $42.6 \pm 49.4 \mathrm{~g}$; $5.6 \pm 14.4 \mathrm{~g}$; dan $9.4 \pm 9.6 \mathrm{~g}$. Jumlah anak yang mengonsumsi bubur ayam $44.4 \%$, mie ins$\tan 14.8 \%$, dan biskuit $48.1 \%$.

Rata-rata konsumsi pangan sumber protein hewani anak balita adalah telur (15.4 \pm $22.8 \mathrm{~g})$, ikan $(6.0 \pm 13.4 \mathrm{~g})$, ayam $(6.0 \pm 11.0$ g), bakso $(5.0 \pm 8.2 \mathrm{~g})$, dan susu $(11.9 \pm 19.0$ g). Jumlah anak balita yang mengkonsumsi pangan hewani hanya sebesar $40.7 \%$. Bahan pangan sumber protein nabati yang biasa dikonsumsi adalah tempe $(6.5 \pm 11.2 \mathrm{~g})$. Tempe hanya dikonsumsi oleh $25,0 \%$ anak.

Jumlah konsumsi sayur bayam $15.0 \pm$ $29.7 \mathrm{~g}$ dan sup $12.0 \pm 24.4 \mathrm{~g}$. Hanya sebagian kecil anak yang mengonsumsi sayur tersebut (22.2\%). Buah yang banyak dikonsumsi adalah semangka $(13.0 \pm 22.3 \mathrm{~g})$ dan jeruk manis $(8.1$ $\pm 19.9 \mathrm{~g})$. Jumlah anak balita yang mengonsumsi buah sebesar $25.9 \%$.

Anak balita memperoleh PMT dari Puskesmas berupa biskuit MP-ASI dan susu formula (Profimilk). Rata-rata berat biskuit MP-ASI yang dikonsumsi anak balita adalah $34.4 \pm 34.1$ g. Namun demikian, hanya sebesar $70.4 \%$ anak balita yang mengonsumsi biskuit MP-ASI. Ratarata konsumsi susu formula adalah $4.8 \pm 8.9 \mathrm{~g}$, dan yang mengonsumsi hanya 29.6\%. Hal ini menunjukkan bahwa PMT Puskesmas tidak memberi kontribusi yang besar untuk konsumsi anak balita. Berdasarkan observasi, PMT ini tidak hanya diberikan kepada anak balita gizi buruk saja tetapi juga anggota rumahtangga yang lain, seperti kakak maupun adiknya.

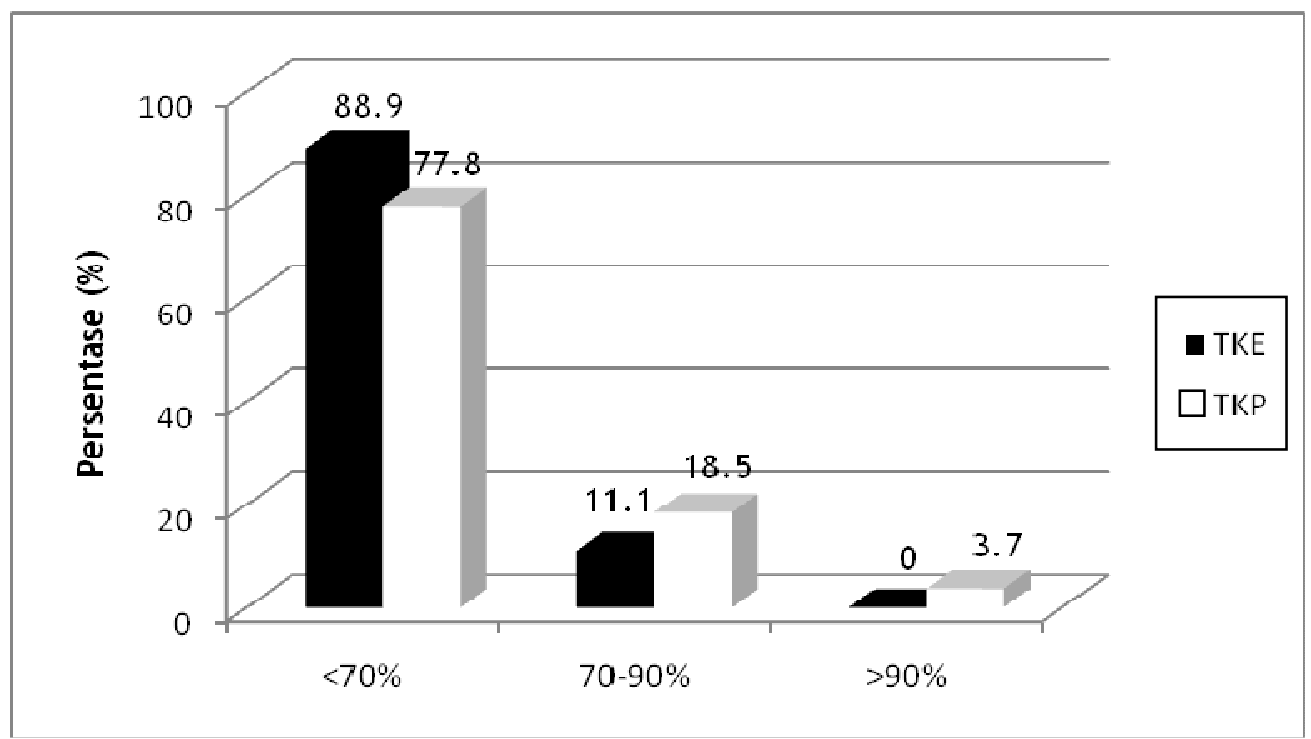

Gambar 1. Tingkat Kecukupan Energi dan Protein (TKE dan TKP) Anak Balita 
Rata-rata asupan energi dan protein aktual anak balita adalah $509 \pm 149$ kkal dan 13.1 \pm 5.2 g. Rata-rata asupan aktual tersebut masih lebih rendah dibandingkan rekomendasi angka kecukupan gizi (AKG). Rata-rata tingkat konsumsi energi (TKE) anak usia 1-3 tahun hanya memenuhi $52.0 \%$ AKE, pada usia 4-6 tahun $55.5 \%$ AKE. Jumlah anak yang tingkat kecukupan energi $<70 \%$ sebanyak $88.9 \%$ (Gambar 1 ).

Asupan protein rata-rata anak balita 1-3 tahun sebesar $13.4 \mathrm{~g} /$ hari. Asupan protein hanya memenuhi 53.5\% Angka Kecukuan Protein (AKP). Anak balita usia 4-6 tahun rata-rata asupan proteinnya $23.5 \mathrm{~g} /$ hari atau hanya memenuhi $60.5 \%$ AKP. Anak balita 1-3 tahun dan 4-6 tahun dianjurkan mengonsumsi protein (AKP) sebesar $25.0 \mathrm{~g}$ dan dan $39.0 \mathrm{~g}$. Sebagian besar anak (77.8\%) kategori defisit berat atau tingkat kecukupan protein <70\% (Gambar 1).

Asupan energi dan protein yang masih rendah tersebut karena nafsu makan anak yang masih kurang. Kondisi ini jika terus terjadi maka akan memperburuk kondisi gizi dan kesehatan. Oleh karena itu, perlu peningkatan konsumsi secara bertahap sesuai dengan kondisi anak balita agar dapat mengejar tumbuh kembangnya.

Pola asuh makan dalam penelitian ini mencakup pemberian makan secara responsif (responsive feeding) dan higiene dari ibu dalam proses pemberian makan kepada anak balita. Distribusi paktek pemberian makan secara responsif oleh ibu meliputi pemberian langsung/pendampingan jika anak sudah dapat makan sendiri sebanyak 96.3\%. Jumlah ibu yang peka (sensitif) dengan tanda/isyarat jika anak lapar ataupun kenyang (77.8\%); ibu memberi makan secara perlahan dan sabar, serta mendorong anak untuk makan (81.5\%). Jika anak menolak beberapa makanan, maka ibu membuat makanan yang berbeda, baik dalam kombinasi, tekstur, rasa, maupun cara membujuknya $(0.0 \%)$. Sebanyak $88.9 \%$ ibu berinteraksi dengan anak selama proses pemberian makan.

Distribusi praktek higiene makanan meliputi ibu mencuci tangan sebelum menyiapkan makanan anak (44.4\%), mencuci tangan anak terlebih dahulu saat anak akan makan (7.4\%), menggunakan peralatan masak dan makan yang bersih (100.0\%), menyajikan makanan segera kepada anak setelah selesai diolah/dimasak (22.2\%), dan menghindari pemberian makanan melalui botol kepada anak (55.6\%). Menurut WHO (2005) $)^{5}$, penggunaan botol merupakan salah satu praktik yang harus dihindari karena menjadi wahana dan transmisi patogen penyebab penyakit diare. Menurut Black et al. (1989) diacu dalam WHO (2005), penelitian di Peru menunjukkan $35.0 \%$ botol susu terkontaminasi E.coli dan $31.0 \%$ penggunaan botol untuk minum teh E.coli. Persentase tersebut cukup tinggi jika dibandingkan penyajian teh dengan menggunakan cangkir atau gelas, yang hanya $2.0 \%$ rentan terkontaminasi E.coli.

\section{Penyakit Infeksi}

Penyakit infeksi diukur dari wawancara kepada ibu berdasarkan laporan diagnosis dokter dan gejala untuk penyakit diare dan ISPA selama tiga bulan terakhir. Hal ini dikarenakan kedua jenis penyakit tersebut sangat rentan terjadi pada anak balita gizi buruk. Kondisi kesehatan anak balita pasca perawatan gizi buruk masih tetap harus dijaga dan dilakukan pemeriksaan dengan segera jika terkena penyakit. Anak balita yang menderita diare dan ISPA dalam waktu yang cukup lama dan sering, maka berat badannya akan turun dan ini akan berpengaruh pada status gizinya.

Sebesar $55.6 \%$ anak balita dalam tiga bulan terakhir menderita diare. Hal ini dapat dimungkinkan karena higiene makanan dan sanitasi di sekitar tempat tinggal yang kurang. Dari observasi keseluruhan anak balita yang masih menggunakan botol susu mengalami diare. Hasil penelitian ini mendukung hasil studi lainnya bahwa penggunaan botol merupakan salah satu faktor penyebab dari kejadian diare pada anak balita.

Selain diare, anak balita pasca perawatan gizi buruk juga rentan dengan penyakit ISPA, jumlah anak yang menderita ISPA sebanyak $59.3 \%$. ISPA yang diderita oleh sebagian besar anak balita ini tergolong kategori ringan yaitu batuk disertai dengan tanda atau gejala seperti pilek, panas atau demam, dan serak.

Pada umumnya, frekuensi sakit diare dan ISPA pada anak balita selama tiga bulan terakhir adalah sebanyak $\geq 3$ kali, dengan persentase masing-masing adalah $55.6 \%$ dan $59.3 \%$. Lama hari sakit diare selama sebulan terakhir adalah $\geq 3$ hari (55.6\%) dan untuk lama hari sakit ISPA adalah $\geq 7$ hari (59.3\%).

\section{Perkembangan Status Gizi}

Kondisi perkembangan berat badan anak balita selama tiga bulan terakhir memperlihatkan bahwa peningkatan berat badan per bulannya masih kecil yaitu sebesar $0.1 \pm 0.2$ kg. Berat badan aktual anak balita adalah 7.7 $\pm 1.4 \mathrm{~kg}$ dan tinggi badan aktual anak balita adalah $77.8 \pm 7.4 \mathrm{~cm}$. 
Status gizi berdasarkan indeks BB/U menggambarkan status gizi pada masa kini. Terlihat bahwa status gizi anak balita masih sama, yaitu sebagian besar (77.8\%) masih dalam kategori gizi buruk. Namun demikian, terlihat juga bahwa mulai ada perubahan status gizi dari status gizi buruk ke status gizi kurang yaitu sebesar $18.5 \%$ anak balita, sehingga saat sekarang anak balita dalam kondisi gizi kurang sebesar 22.2\% (Tabel 2).

Kondisi anak balita dilihat dari status gizi dengan indeks TB/U menunjukkan tidak ada perubahan yang signifikan (Tabel 2). Sebesar 81.5\% anak balita yang saat awal perawatan tergolong pendek, sampai sekarang pun masih tergolong pendek. Hanya $18.5 \%$ anak balita yang sekarang kondisinya menjadi normal.

Indeks antropometri BB/TB menggambarkan status gizi di masa kini dan indeks ini baik digunakan jika data usia tidak diketahui. Indeks ini merupakan indikator wasting (kurus). Berdasarkan indeks BB/TB terjadi perubahan yang cukup signifikan yaitu dari $100 \%$ awal perawatan sangat kurus, kemudian kondisi sekarang bergeser kurus sebesar 48.1\% (Tabel 2).

Kondisi perkembangan status gizi anak balita pasca perawatan gizi buruk dilihat berdasarkan gabungan indeks antropometri (BB/U, $\mathrm{TB} / \mathrm{U}$, dan $\mathrm{BB} / \mathrm{TB})$. Dengan gabungan ketiga indeks tersebut menunjukkan sebesar $81.5 \%$ balita masih dalam kondisi gizi buruk, dari dulu sampai kini.

Tabel 2. Status Gizi Anak Balita berdasarkan $\mathrm{BB} / \mathrm{U}$, TB/U, dan BB/TB Pada Saat Awal dan Sekarang

\begin{tabular}{lcccc}
\hline \multirow{2}{*}{ Indeks Status Gizi } & \multicolumn{2}{c}{ Awal } & \multicolumn{2}{c}{ Sekarang } \\
\cline { 2 - 5 } & $\mathrm{n}$ & $\%$ & $\mathrm{n}$ & $\%$ \\
\hline Indeks BB/U & 26 & 96.3 & 21 & 77.8 \\
Gizi buruk (<-3 SD) & 1 & 3.7 & 6 & 22.2 \\
Gizi kurang (-3 s/d -2 SD) & 0 & 0.0 & 0 & 0.0 \\
Gizi baik (-2 s/d +2 SD) & & & & \\
\hline Indeks TB/U & 23 & 85.2 & 22 & 81.5 \\
Pendek (<-2 SD) & 4 & 14.8 & 5 & 18.5 \\
Normal ( $\geq-2$ SD) & & & & \\
\hline Indeks BB/TB & 27 & 100.0 & 14 & 51.9 \\
Sangat Kurus (<-3 SD) & 0 & 0.0 & 13 & 48.1 \\
Kurus (-3 S/d -2 SD) & 0 & 0.0 & 0 & 0.0 \\
Normal (>+2 SD) & & & & \\
\hline
\end{tabular}

Hasil uji korelasi Pearson menunjukkan bahwa TKE memiliki hubungan yang positif dan signifikan dengan status gizi anak balita berda- sarkan $B B / U(r=0.416 ; p<0.05)$ dan $T B / U(r=$ 0.389; $p<0.05$ ), sedangkan dengan $B B / T B$ tidak ada hubungan $(p>0.05)$. Hal ini berarti bahwa semakin baik tingkat kecukupan energi anak balita, maka status gizi anak balita menurut $\mathrm{BB} / \mathrm{U}$ dan $\mathrm{TB} / \mathrm{U}$ semakin baik. Kondisi ini disebabkan berat badan (BB) lebih memberi gambaran tentang masa tubuh (otot dan lemak) yang sangat sensitif terhadap perubahan tentang masa tubuh.

Kondisi yang sama juga terlihat pada TKP, yaitu terdapat hubungan positif yang signifikan dengan status gizi anak balita berdasarkan BB/U ( $r=0.515 ; p<0.01)$ dan TB/U ( $r=0.481$; $p<0.05)$. Namun, tidak ada hubungan antara TKP dengan status gizi anak balita berdasarkan $B B / T B(p>0.05)$.

Kejadian diare (frekuensi) pada anak balita mempunyai hubungan yang negatif dengan status gizi anak balita berdasarkan BB/U $(r=$ $-0.488 ; p<0.01)$ dan TB/U $(r=-0.394 ; p<$ 0.05), sedangkan berdasarkan BB/TB tidak ada hubungan $(p>0.05)$. Hal ini berarti bahwa semakin sering diare maka status gizi anak balita menurut $\mathrm{BB} / \mathrm{U}$ dan $\mathrm{TB} / \mathrm{U}$ semakin buruk.

Kejadian ISPA (frekuensi) pada anak balita mempunyai hubungan negative dengan status gizi anak balita berdasarkan BB/U $(r=$ $-0.426 ; p<0.05)$ dan $B B / T B(r=-0.404 p<0.05)$, sedangkan berdasarkan TB/U tidak ada hubungan $(p>0.05)$.

\section{KESIMPULAN}

Konsumsi pangan anak balita pasca perawatan gizi buruk di Puskesmas masih belum baik. Tingkat kecukupan energi dan protein sebagian besar masih berada dalam kondisi defisit berat $(88.9 \%$ dan $77.8 \%)$. Rendahnya tingkat kecukupan energi dan protein tersebut diantaranya karena kemampuan daya dan praktek pengasuhan makan yang rendah, terutama upaya pada anak yang kesulitan makan.

Kondisi anak balita pasca perawatan gizi buruk masih rentan terhadap penyakit infeksi. Sebagian besar anak menderita diare (55.6\%) dan ISPA (59.3\%) dengan frekuensi sakit $\geq 3$ kali. Sebagian besar anak mengalami sakit diare $\geq 3$ hari $(55.6 \%)$ dan ISPA $\geq 7$ hari (59.3\%).

Status gizi anak balita berdasarkan indeks BB/U, TB/U, dan BB/TB tidak menunjukkan perbaikan yang signifikan setelah perawatan di Puskesmas. Setelah 2-8 bulan pasca perawatan, $77.8 \%$ balita menderita underweight berat $(\mathrm{BB} / \mathrm{U}), 81.5 \%$ stunted $(\mathrm{TB} / \mathrm{U})$, dan $51.9 \%$ 
wasted. Dengan ketiga indeks tersebut, sebagian besar anak balita (81.5\%) masih dalam kategori gizi buruk dan hanya $18.5 \%$ yang mengarah pada perbaikan gizi tingkat sedang.

Latar belakang keluarga anak balita gizi buruk adalah dari sosial ekonomi rendah. Untuk itu diperlukan upaya peningkatan akses sumber pangan bergizi serta ketrampilan dalam penyajian menu anak balita.

Petugas kesehatan perlu melakukan kunjungan (visit) ke rumah anak balita gizi buruk untuk mengawasi dan membantu keluarga dalam mempraktekan perawatan dan pengasuhan anak yang benar.

\section{UCAPAN TERIMA KASIH}

Penulis menyampaikan terima kasih kepada Dinas Kesehatan Kabupaten Bogor, Puskesmas Cibungbulang, Ciampea, Lewiliang, Kampung Manggis (Dramaga) yang telah memberikan rekomendasi kepada kami sehingga dapat melakukan penelitian ini. Demikian pula penghargaan yang tinggi disampaikan kepada ibu anak balita yang telah bersedia menjadi responden.

\section{DAFTAR PUSTAKA}

Arnelia. 2009. Tatalaksana balita gizi buruk secara rawat jalan. Di dalam: Laporan Kegiatan Pelatihan Klinik Gizi Petugas Puskesmas; Cisarua, 26-28 Mei 2009. Dinas Kesehatan Kabupaten Bogor, Bogor.
Arnelia, Lamid A, Muljati S, \& Matulessy P. 1992. Keragaan anak balita pasca pemulihan gizi buruk. Penelitian Gizi dan Makanan 15:29-37.

Arnisam. 2007. Hubungan berat badan lahir rendah (BBLR) dengan status gizi anak usia 6-24 bulan [tesis]. Universitas Gad- jah Mada, Yogyakarta.

[Depkes RI] Departemen Kesehatan Republik Indonesia. 2008a. Sistem Kewaspadaan Dini (SKD) KLB-Gizi Buruk. Badan Penelitian dan Pengembangan Kesehatan, Jakarta.

[Depkes RI] Departemen Kesehatan Republik Indonesia. 2008b. Riset Kesehatan Dasar (Riskesdas) 2007. Badan Penelitian dan Pengembangan Kesehatan, Jakarta.

[Depkes RI] Departemen Kesehatan Republik Indonesia. 2009. Buku Kesehatan Ibu dan Anak. Departemen Kesehatan Republik Indonesia, Jakarta.

Gibson RS. 2005. Principles of Nutritional Assessment. Oxford University Press, Oxford, UK.

[WHO] World Health Organization. 2005. Guiding Principles for Feeding Non-Breastfed Children 6-24 Months of Age. WHO Press, Geneva. 